\title{
臨床研究
}

\section{日常診療における緊急 ERCPへの対応}

\author{
小泉優子 今村綱男 小山里香子 奥田近夫 \\ 竹内和男
}

\begin{abstract}
要旨: 胆膵領域では緊急処置を必要とする致死的な病態が日常的に存在する。処置の主と なる内視鏡的逆行性膵胆管造影 $(\mathrm{ERCP})$ は熟練した術者, 介助者, X線透視操作者, 器具出 しなど外回りといったマンパワーを必要とし，緊急で施行することに難渋することが少な くない。当院における緊急ERCPの実態について調査した。2006年 1 月から 2 年間におけ る自験例 594 症例のうち, 約 $1 / 4$ 占める146例に対し, 緊急的にERCPを行っており, 特に 急性胆管炎が125例と大多数を占めた。これらを retrospectiveに急性胆道炎の診療ガイド ラインと照らし合わせると，重症急性胆管炎の場合，疾患・時間帯を問わず全症例で速や かにERCPを施行していた。中等症および軽症急性胆管炎の場合, 原疾患が総胆管結石や 悪性腫瘍における胆管ステント閉塞の場合は，速やかに施行していた。一方，悪性腫瘍初 発例の場合は，胆管炎が保存的治療が可能であればCTPEUS等の画像検索を先行し待期 的に行う例が多かった。重症度分類を用いての緊急ERCPのトリアージに関しては，重症 のうち「菌血症」の有無は発症時には確定できないことと, 中等症のうち「黄疸」の項目は原 疾患が悪性腫瘍の場合には高頻度に該当してしまう点が，臨床的矛盾点として考えられた。 ERCPにより急性胆管炎は全例改善しており, 有用な治療手段であった。実施時期に関して は来院時間帯や検査室の状況が大きく関与していた。
\end{abstract}

〔Key Words〕 緊急 ERCP, 急性胆管炎, ガイドライン

\section{はじめに}

胆荤領域では緊急処置を必要とする致死的な病 態が日常的に存在する ${ }^{11}$ 。平成18年 3 月に急性胆 管炎・胆囊炎に, 平成19年 3 月に胆石性腪炎に対 して，それぞれ診療ガイドライン ${ }^{2,3}$ が刊行され， EBMに基づいた緊急内視鏡的処置の適応とその タイミングや手技に関する施行基準が提唱されて いる。これらの緊急内視鏡の適応となる病態に対 して, 胆道ドレナージを行う際, 内視鏡的ドレ ナージが, 経皮経肝的あるいは開腹ドレナージに 比し合併症発症率や患者負担の点から ${ }^{4 \sim 6)}$, 強く奨 められている。しかしながら, 臨床の場において は内視鏡的逆行性膵胆管造影 (endoscopic retrograde cholangiopancreatography ; 以下, ERCP) は熟練した術者, 介助者, X線透視操作者, 器具 出しなど外回りといったマンパワーを必要とし， 緊急で施行することに難渋することが少なくない。

本稿では，当院における緊急ERCPの実態につ いて調査し，その適応について検討するとともに， 虎の門病院/消化器科
施行決定に際し診療ガイドラインを活用すること の有用性につき考察を加え報告する。

\section{対象と方法}

当院で2008年現在のコンピューターオーダリン グシステムが導入された 2006 年 1 月から 2 年間の $\mathrm{ERCP}$ 全646例のうち, レポート検索が可能であっ た594例を対象とした。

発症または来院から 2 病日以内に ERCPが施行 された症例を緊急 $\mathrm{ERCP}$ と設定し, その背景を検 討した。

\section{結 果}

\section{患者背景}

対象となった594症例のうち，146例 (24.6\%)に 対し, 緊急 ERCPを行っていた。内訳は男性102例, 女性 44 例, 年齢22〜94歳 (中央值68歳)であった。 原疾患は全例が胆管目的であり, 総胆管結石が過 半数を占めた (Table 1)。施行理由は急性胆管炎 が125例 $(85.6 \%)$ と大多数を占め, 以下黄疸のみが 
Table 1 Cases of emergency ERCP in our hospital.

\begin{tabular}{lll}
\hline 原疾患 & 例数 & $(\%)$ \\
\hline 総胆管結石 & 81 & $(55.5)$ \\
膵癌 & 24 & $(16.4)$ \\
胆管癌 & 14 & $(9.4)$ \\
胆囊結石 & 7 & $(4.8)$ \\
肝細胞癌 & 5 & $(3.4)$ \\
乳頭部癌 & 3 & $(2.1)$ \\
その他 & 12 & $(8.2)$ \\
\hline 合計 & 146 例 & \\
\hline
\end{tabular}

9 例 (6.1\%), 腹痛 7 例 (4.8\%), 肝胆道系酵素上昇 2 例 $(1.4 \%)$ ，その他 3 例 (2.1\%) であった。

\section{疾患 1 ：急性胆管炎}

急性胆管炎に対し，緊急・待期的問わず ERCP を施行した症例はERCP 594例中280例であった。 これらの症例を, 急性胆管炎・胆囊炎の診療ガイ ドライン (第 1 版) 重症度判定基準 (Table 2)に則 り, retrospectiveに検討すると, 280 症中10例 (3.6\%) が重症, 185例 (66.1\%) が中等症, 85例 (30.3 \%)が軽症であった。それぞれ重症度別に, 原疾患 と内視鏡治療のタイミングを調査する。

ガイドラインにretrospectiveに照らし合わせ た結果重症の場合，原疾患や時間帯を問わず同意 が得られ次第, 全例で速やかにERCPを施行して いた。これらは, 重症度判定基準の重症の項目の うち, 全例菌血症のみを満たしていたが, ERCP施 行時点では菌血症の有無は不明のため, 発熱や炎 症反応など感染徵候が著しいことや, 強い腹痛が あるといった臨床徴候が, 緊急的にERCPを行う 動機となった。

ガイドライン上で中等症の場合，185例中 105 例 (56.8\%) が待期的に施行され, 80 例 (43.2\%) が緊急 的に成されていた。各々の原疾患の内訳は，待期 的に ERCPを行う症例では悪性腫瘍が56例と多く, 一方緊急例では総胆管結石が 42 例と最も多い原因 であった。ほぼ全例，「黄疸」で判定基準を満たし
Table 2 Criteria of severity in acute cholangitis.

\begin{tabular}{|c|}
\hline 急性胆管炎の重症度判定基準 \\
\hline 口重症急性胆管炎 \\
\hline 急性胆管炎の内、以下のいずれかを伴う場合は「重症」である \\
\hline (1) ショック \\
\hline (2) 菌血症 \\
\hline （3）意識障害 \\
\hline (4) 急性腎不全 \\
\hline 日中等症急性胆管炎 \\
\hline 急性胆管炎の内、以下のいずれかを伴う場合は「中等症」とする \\
\hline (1) 黄症(ビリルビン>2.0mg/dl) \\
\hline (2) 低アルブミン血症(アルブミン $<3.0 \mathrm{~g} / \mathrm{dl})$ \\
\hline (3) 腎機能障害(クレアチニン>1.5mg/dl, 尿素窒素>20mg/dl) \\
\hline (4) 血小板減少*(<12 万/mm³) \\
\hline (5) $39^{\circ} \mathrm{C}$ 以上の高熱 \\
\hline 口軽症急性胆管炎 \\
\hline 急性胆管炎の内、「重症」「中等症」の基準を満たさないものを「軽症」とする \\
\hline
\end{tabular}

中等症と分類されていた。中等症胆管炎の原因と して総胆管結石の場合は, 日勤時間であれば速や かに施行され，時間外では保存的治療がなされた 後, 翌朝改善がないか, 改善していても検査件数 に余裕があれば速やかに施行した。抗凝固剤の服 用や，スタッフおよび検查室の都合上，待期的に 施行する症例も認められた。

一方，悪性腫瘍の場合は黄疸 (T.bil > $2 \mathrm{mg} / \mathrm{dl}$ ) を容易に満たし中等症と分類されてしまうが，そ の後の治療方針を考慮し造影 CT P EUS等の画像 検索を胆道ドレナージ前に優先して行うため, 胆 管炎のコントロールが可能であれば分類は中等症 であっても待期的に行う症例が多かった。

ガイドライン上で軽症の場合，緊急施行例が 36 例 (42.4\%)，待期的施行例は49例 (57.6\%)であった。 両者ともに総胆管結石が最多であった。総胆管結 石症例では, 患者側因子 (抗凝固剂服用など) やス タッフの状況により不可能な場合を除いて, 診断 確定後 2 日以内に施行する緊急例の割合が高かっ た。

以上のような対応で, 全例で胆管炎の改善が得 られた。

\section{疾患 2 : 悪性胆管狭窄の初発例}

悪性胆管狭窄の初発例に対して, 診断および治 療を目的として, ERCPが施行された症例は165例 であった。原疾患は膵癌75例 (45.4\%), 胆管癌52例 (31.5\%), IPMN 13例 (7.9\%), 乳頭部癌10例 (6.1\%), 肝細胞癌 9 例 $(5.5 \%)$, 胆囊癌 6 例 (3.6\%) であった。 


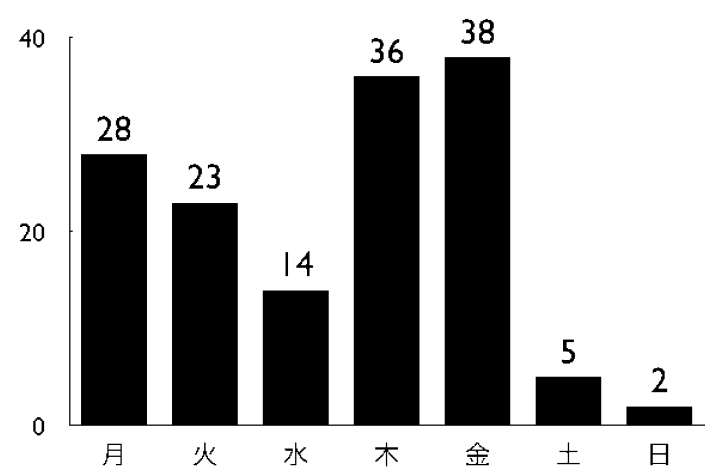

Fig. 1 Cases of emergency ERCP on every day of the week.

初発例の場合，高度な胆管炎症例および他院で診 断および治療方針決定に十分な画像検索が済んで いた 21 例 $(13 \%)$ を除く 144 症例 $(87 \%)$ で待期的に ERCPが施行されていた。これらの症例には前述 のごとくほぼ全例にUSおよび造影CTを，さらに 必要と考えられた症例にはMRCPPEUSを施行 した後にERCPを施行していた。

\section{疾患 3 : 悪性胆管狭窄の胆管ステント閉塞}

一方，悪性腫瘍でも胆管ステント閉塞の場合で は，対象となった 26 例のうち， 6 例 (23\%)に於い て緊急的に，20例 $(77 \%)$ に於いて待期的に ERCP が行われていた。切除不能症例が多く, CTなど画 像検査が不要のため, 初発例に比べ緊急 ERCPを 行った割合が高かった。一方，原疾患による全身 状態不良や検査室の状況などにより待期的に行わ ざるを得ない症例も多かった。

\section{曜日別検査件数}

当院では火・木が検査日であるが，重症胆管炎 等の特殊な場合を除き，休日前の金曜日，もしく は明けて月曜日に緊急処置の件数が多くなってい た $($ Fig. 1)。

\section{考 察}

胆荤領域で緊急内視鏡的処置を必要とする疾患 は, 急性胆道炎や胆石性㬸炎》が主であるが, 病態 が複雑な場合も多く, 症例ごとに適切な対応が重 要である。緊急内視鏡的処置は自覚症状や理学所 見・血液検查・画像検查など客観的検査から臨床 的な重症度を判断するとともに，上部消化管手術
や消化管再建術などの既往歴や, 抗凝固薬・抗血 小板薬など常用薬の有無といった総合的な病態を 考慮しながら適応を検討し，タイミングを冕する ことなく施行しなければならない。当院では, ERCPの施行時期に関して定まった基準というも のは作成していないが，概ね以下の様な対応をし ている。(1)急性胆管炎では, 発熱や炎症反応など 感染徵候が著しい場合や, 強い腹痛があるといっ た臨床徴候が高度な場合には緊急 ERCPを行う。

(2)臨床徴候が軽度で保存的治療が可能と判断され た胆管炎では，原疾患や炎症の程度，さらに来院 時間や検査室の状況等様々な要素を考慮しながら， 遅滞することなく ERCPを施行する。(3)抗凝固剂 服用例は服薬停止後一定期間後に施行する。当院 では，ワーファリンの場合は休薬期間を 5 日間, バイアスピリンは 7 日間としている。(4)悪性腫 瘍による全身状態不良例には，患者および家族の 同意が得られ，かつ $\mathrm{ERCP}$ 施行により PSの改善が 見込まれる場合に，慎重に施行を決定する。この ような対応で，内視鏡治療を施行した急性胆管炎 症例は全例改善しており, 今後も基本的には同じ 方針で診療して特に問題はないと考えている。

一方，診療ガイドラインによる重症度分類に関 しては緊急ERCPのトリアージとほぼ一致してお り, 特に重症例は病態をよく反映していると考え られた。しかしながら重症のうち菌血症の有無は 血液培養の結果が少なくとも 1 ～ 2 日を要するた め発症時には不明であること(緊急 ERCP施行の 適応判断時には使用できない), 中等症の黄疸 (T.bil > $2 \mathrm{mg} / \mathrm{dl}$ ) の項目は悪性腫瘍では高頻度に 当てはまってしまうため, 発熱や炎症反応が軽度 であり他の画像検査を先行して経過に問題のな かった症例でも中等症に分類されてしまう点が, 臨床的矛盾点として考えられた。

さらに, 緊急医療行為には安全確保が要求され, とりわけ胆膵領域の緊急内視鏡手技は難度が高い とされているため, 医学的適応のみでなく, 医療 スタッフ側の適応条件も考慮しなければならない。 すなわち, 手技に熟練した内視鏡医, 器具の扱い を習熟した介助者, X線透視操作者, 術中の患者 の状態を監視する外回りなど複数の医療スタッフ によるチーム医療が久かせない。当院では，昼間 の時間帯では術者・介助者 $(X$ 線操作を兼ねる) ・ 
内視鏡技師の最低 3 人で行い，時に研修医が 1 2 名介助 - 外回りに加わるが, 看護師やX線操作 を担当する放射線技師は同席しない。夜間では術 者の他，介助者が $1 \sim 2$ 名付くが ERCPに不慣れ な場合も多い。当院にて $\mathrm{ERCP}$ 関連手技を完遂す ることの可能な医師は 2 名と少なく，夜間の処置 は必然的に多大な負担がかかってしまう現状にあ る。これらの事象は内視鏡手技に関わる偶発症の 発生を招き，結果として患者の不利益につながる。 したがって，熟練した術者・介助者および内視鏡 技師が揃い安全に遂行可能な態勢を十分に整えて から胆膵内視鏡治療は行われるべきである ${ }^{8)}$ 。今 回の曜日別検討においても，休日前後の金曜・月 曜に緊急ERCPが多い結果となった。医療従事者 における時間外労働の改善がなければマンパワー の確保が難しく，現状のような条件下で胆腪内視 鏡医にかかるストレスは計り知れない。

\section{おわりに}

緊急 $\mathrm{ERCP}$ は，胆荤緊急疾患，特に急性胆管炎 に有用な治療手段であった。その適応決定には医 学的適応だけではなく来院時間帯や検査室の状況 等が大きく関与していた。
急性胆管炎の診療ガイドラインは重症度をよく 反映しており，高齢者，悪性疾患による全身状態 不良患者, 心・呼吸・肝・腎疾患などの High risk な症例で施行時期に迷う際には，ガイドラインに よって適切な判断ができる可能性が期待されるが, 臨床で迅速に活用するには一部問題が考えられた。

\section{文 献}

1) Reynolds BM, Dargan EL. Acute obstructive cholangitisA distinct syndrome—. Ann Surg 150:299-303, 1959.

2 ) 急性胆道炎の診療ガイドライン作成出版委員会(編)：科学 的根拠に基づく急性胆管炎・胆囊炎の診療ガイドライン 第 1 版. 医学図書出版, 2005 .

3 ）急性荤炎の診療ガイドライン作成委員会(編)：エビデンス に基づいた急性荤炎の診療ガイドライン 第 2 版. 金原出 版, 東京, 2007.

4) Hanau LH, Steigbigel NH : Acute cholangitis. Infect Dis Clin North Am $14: 521-546,2000$.

5 ) Lai EC, Mok FP, Tan ES, et al : Endoscopic biliary drainage for severe acute cholangitis. N Engl J Med 24 : 15821586, 1992

6 ) Lee DWH, Chung SCS : Biliary infection. Billirers Clin Gastroenterol 11:707-24, 1997.

7 ) Acosta JM, Katkhouda N, Debian KA et al : Early ductal decompression versus conservative management for gallstone pancreatits with ampullary obstruction. Ann Surg $243: 33-40,2006$.

8 ) 小越和栄, 多田生大, 熊井浩一郎, 他 : 消化器内視鏡リスク マネージメント. Gastroenterol Endosc 46:2600-2609, 2004.

\section{Emergency ERCP in our hospital}

Yuko Koizumi Tsunao Imamura Rikako koyama Chikao Okuda Kazuo Takeuchi 